Original Research Article

\title{
Comparative evaluation of effect of green tea and green coffee on blood cholesterol level and body weight in albino rats
}

\author{
Ratan Kumar*, Manoj Kumar Purty
}

Department of Pharmacology, MGM Medical College, Jamshedpur, Jharkhand, India

Received: 10 August 2018

Revised: 14 September 2018

Accepted: 18 September 2018

*Correspondence to:

Dr. Ratan Kumar,

Email: drratan58@gmail.com

Copyright: (C) the author(s), publisher and licensee Medip Academy. This is an openaccess article distributed under the terms of the Creative Commons Attribution NonCommercial License, which permits unrestricted noncommercial use, distribution, and reproduction in any medium, provided the original work is properly cited.

\begin{abstract}
Background: Overweight and obesity are chronic medical condition responsible for risk factors for many non-communicable diseases. Development of rapid upsurge of these condition in medium and low-income group countries increased the awareness and uses of many types of remedies. Along with other natural herbal products green tea and green coffee have also became popular in communities. Aim of this study was to compare the effect of green tea and green coffee on blood cholesterol and weight in experimental animals.

Methods: The experiment of this study was conducted in the Department of Pharmacology, MGM Medical college, Jamshedpur after ethical approval. 24 albino rats were selected and divided randomly in four groups A B C D. Group ' $A$ ' was kept as control group, group 'B' was given fat rich diet to produce hypercholesterolemia, group ' $\mathrm{C}$ ' and ' $\mathrm{D}$ ' were given green tea and green coffee respectively along with cholesterol rich diet. Weight and cholesterol level of rats were measured on $1^{\text {st }}$ day, $2^{\text {nd }}$ week and $4^{\text {th }}$ week.

Results: There was significant increase in serum cholesterol in non-treated animals as compared to control group but parameter showed significant less rise of cholesterol and weight in treated group by both green tea and green coffee than non-treated group. The comparative effect of green tea and green coffee had not much difference.

Conclusions: This study has provided the information that natural products like green tea and green coffee are useful and helpful in preventive therapy of dyslipidemia and obesity.
\end{abstract}

Keywords: Green tea, Green coffee, Overweight, Obesity

\section{INTRODUCTION}

According to WHO, overweight and obesity are defined as abnormal or excessive fat accumulation that present a risk to health. A crude population measure of obesity is body mass index (BMI). BMI $\geq 25$ and $\geq 30$ are considered as overweight and obesity respectively. ${ }^{1}$

In 2016 more than 1.9 billion adults of 18 years and above were overweight. Female ratio is more than male. Over 340 million children and adolescent of 05 to 19 years age group are overweight or obese. ${ }^{1}$ Unhealthy high calorie, fat rich diet and physical inactivity are key factors for major non-communicable diseases.

Diet, exercise and behavioral therapy are recommended for all patient with $\mathrm{BMI}>25 \mathrm{~kg} / \mathrm{m}^{2}$. Pharmacotherapy to bariatric surgery are considered for patient with BMI $>40 \mathrm{~kg} / \mathrm{m}^{2}{ }^{2}$ Globally including our country there are many remedies derived from natural source are very common and popular, being used for control of bodyweight, diabetes mellitus, hypertension and for maintenance of good health. Among the home remedies green tea is well known established naturally derived product and now green coffee has been under common use for same purposes. 
Green tea is a type of tea that is made from Camellia sines is which have not undergone the process of withering and oxidation. This contains antioxidants and, beneficial polyphenols. Consumption of green tea have shown corelation with reduced risk of death from cardiovascular diseases. It may also have favourable effect on blood pressure, blood glucose, blood cholesterol and body weight. It is found that countries have lower cancer rate where green tea consumption is high but have no strong evidence. $^{3}$ Several studies show that flavonoids and caffeine in green tea increases fat oxidation, improve insulin activity and help in weight reduction. ${ }^{4-6}$

Green coffee (Coffea Arabica) is cultivated in Brazil, Cuba, Vietnam and also in India. Green coffee bean seeds of fruit that is non-roasted have high level of chlorogenic acid and many antioxidants as compare with regular roasted coffee. The contents of chlorogenic acid in green coffee is said be responsible for inhibiting conversion of glucose into fat. ${ }^{7}$ Broadly this natural product is also considered as a health friendly in overweight person, in obesity, diabetic, hypertensive patients and in Alzheimer disease. ${ }^{8}$ Green coffee contains caffeine similar to regular one therefore can cause caffeine related side effects.

\section{METHODS}

The study was carried out in the Dept. of Pharmacology, MGM Medical College Jamshedpur.

Green tea was obtained as a gift for personal use, (manufactured and marketed by Madhu Jayanti Int. Pvt Ltd. Kolkata -700023 , one bag contains $1.5 \mathrm{gm}$ green tea) Green coffee was obtained as a gift for personal use (manufactured by Sanzyme (p) Ltd, Hyderabad -500052), one bag contain $2 \mathrm{gm}$ green coffee. Both products are available in the market for common use for the society/community. One sachet of green tea contains $1.5 \mathrm{gm}$ in small granules, similarly one sachet of green coffee contains $2 \mathrm{gm}$ of coffee in powder form. Albino rats were obtained from Kolkata through local supplier.

All the animals used in our study were taken care of under ethical consideration after approval from ethical committee of MGM Medical College.

\section{Experimental design}

Twenty-four albino rats of either sex weighing 100-200 gm were taken for this study. The animals were divided randomly in four groups $(\mathrm{A}, \mathrm{B}, \mathrm{C}, \mathrm{D})$ of six rats in each group. The animals were maintained on a standardized diet and water ad libitum. For experimental purpose the animals were kept fasting overnight but allowed free access to water.

Total duration of experiment was 05 weeks, in which first one week was spent to acclimatization of animals. At starting day of experiment all animals were weighed with estimation of serum cholesterol. Then animals of group A were given standard diet served as control group, similarly group B received standard diet plus egg yolk orally $20 \%$ of total diet $(5 \mathrm{gm})$ daily. Animals of group $\mathrm{C}$ were given similar to group B plus $10 \mathrm{mg}$ of green tea in $2 \mathrm{ml}$ in luke warm water daily. Group D was provided similar to group B plus $10 \mathrm{mg}$ of green coffee in $2 \mathrm{ml}$ in luke warm water daily. Weight of animals were taken at every two-weeks, blood cholesterol was estimated in two weeks interval on $3^{\text {rd }}$ and $5^{\text {th }}$ week. In our experiment blood was collected from tail of the rats. After experiment all necessary care was provided to the animals.

\section{Biochemical analysis}

The serum cholesterol was estimated by Cholesterol kit (CHOD/PAO method)

\section{Statistical analysis}

The data were subjected to statistical analysis using twotailed t-test of unequal variance. $\mathrm{P}$ value $\leq 0.01$ was considered statistically significant.

\section{RESULTS}

Table 1 shows the level of blood cholesterol and weight of animals of control group ' $A$ ' $(n=06)$, and high cholesterol fed animals group ' $\mathrm{B}$ ' $(\mathrm{n}=06)$. Both bodyweight and blood cholesterol level of the albino rats of group 'B', fed with high cholesterol diet (egg yolk: $5 \mathrm{gm} /$ day) is slightly raised in $2^{\text {nd }}$ week and significantly on $4^{\text {th }}$ week as compared with control group 'A' with normal diet $(\mathrm{p}<0.01)$.

Table 1: Observational data of weight and cholesterol of albino rats of group A, and B, from $1^{\text {st }}$ day to $4^{\text {th }}$ week.

\begin{tabular}{|c|c|c|c|c|c|c|c|c|c|c|c|}
\hline \multicolumn{6}{|c|}{ Group A } & \multicolumn{6}{|c|}{ Group B } \\
\hline \multicolumn{3}{|c|}{ Weight (gm) } & \multicolumn{3}{|c|}{ Total cholesterol (mg/dl) } & \multicolumn{2}{|c|}{ Weight (gm) } & \multicolumn{4}{|c|}{ Total cholesterol } \\
\hline $\begin{array}{l}1^{\text {st }} \\
\text { day }\end{array}$ & $\begin{array}{l}2^{\text {nd }} \\
\text { week }\end{array}$ & $\begin{array}{l}4^{\text {th }} \\
\text { week }\end{array}$ & $\begin{array}{l}1^{\mathrm{ST}} \\
\text { day }\end{array}$ & $\begin{array}{l}\mathbf{2}^{\text {nd }} \\
\text { week }\end{array}$ & $\begin{array}{l}4^{\text {th }} \\
\text { week }\end{array}$ & $\begin{array}{l}\mathbf{1}^{\mathrm{ST}} \\
\text { day }\end{array}$ & $\begin{array}{l}2^{\text {nd }} \\
\text { week }\end{array}$ & $\begin{array}{l}4^{\text {th }} \\
\text { week }\end{array}$ & $\begin{array}{l}1^{\mathrm{ST}} \\
\text { day }\end{array}$ & $\begin{array}{l}2^{\text {nd }} \\
\text { week }\end{array}$ & $\begin{array}{l}4^{\text {th }} \\
\text { week }\end{array}$ \\
\hline 100.5 & 100.4 & 100.2 & 74.5 & 74.2 & 74.4 & 100.6 & 104.5 & 110.4 & 75.5 & 80.2 & 101.2 \\
\hline 100.6 & 100.5 & 100.4 & 76.2 & 72.2 & 74.2 & 102.4 & 103.6 & 118.5 & 76.4 & 82.6 & 102.4 \\
\hline 102.2 & 102.5 & 101.4 & 80.6 & 78.8 & 78.2 & 104.2 & 108.4 & 120.4 & 80.4 & 90.4 & 106.4 \\
\hline 104.6 & 104.2 & 102.5 & 82.2 & 81.8 & 80.2 & 106.2 & 106.2 & 116.6 & 82.6 & 89.8 & 104.2 \\
\hline 100.5 & 101.2 & 101.1 & 76.8 & 76.4 & 75.3 & 100.6 & 108.5 & 121.2 & 84.2 & 92.2 & 106.4 \\
\hline 101.4 & 99.5 & 99 & 78.2 & 78.4 & 76.6 & 102.4 & 105.5 & 116.8 & 81.6 & 90 & 102.8 \\
\hline
\end{tabular}


Table 2: Observational data of weight and cholesterol of albino rats of group C and D from $1^{\text {st }}$ day to $4^{\text {th }}$ week.

\begin{tabular}{|c|c|c|c|c|c|c|c|c|c|c|c|}
\hline \multicolumn{6}{|c|}{ Group C } & \multicolumn{6}{|c|}{ Group D } \\
\hline \multicolumn{3}{|c|}{ Weight (gm) } & \multicolumn{3}{|c|}{ Total cholesterol (mg/dl) } & \multicolumn{2}{|c|}{ Weight (gm) } & \multicolumn{4}{|c|}{ Total cholesterol } \\
\hline $\begin{array}{l}1^{\text {st }} \\
\text { day }\end{array}$ & $\begin{array}{l}2^{\text {nd }} \\
\text { week }\end{array}$ & $\begin{array}{l}4^{\text {th }} \\
\text { week }\end{array}$ & $\begin{array}{l}1^{\mathrm{ST}} \\
\text { day }\end{array}$ & $\begin{array}{l}2^{\text {nd }} \\
\text { week }\end{array}$ & $\begin{array}{l}4^{\text {th }} \\
\text { week }\end{array}$ & $\begin{array}{l}1^{\mathrm{ST}} \\
\text { day }\end{array}$ & $\begin{array}{l}2^{\text {nd }} \\
\text { week }\end{array}$ & $\begin{array}{l}4^{\text {th }} \\
\text { week }\end{array}$ & $\begin{array}{l}1^{\mathrm{ST}} \\
\text { day }\end{array}$ & $\begin{array}{l}2^{\text {nd }} \\
\text { week }\end{array}$ & $\begin{array}{l}4^{\text {th }} \\
\text { week }\end{array}$ \\
\hline 102.4 & 103.4 & 106.2 & 78.2 & 78.8 & 84.2 & 106.2 & 110.2 & 11.2 & 82.6 & 83.4 & 87.8 \\
\hline 102.2 & 104.2 & 106.6 & 77.8 & 78.2 & 82.8 & 104.4 & 108.4 & 110.4 & 84.2 & 85.6 & 90.4 \\
\hline 104.6 & 108.6 & 110.4 & 76.8 & 78.4 & 85.6 & 100.4 & 104.4 & 108.2 & 76.8 & 78.4 & 85.2 \\
\hline 108 & 110.2 & 112 & 80.4 & 80.4 & 86.4 & 102.6 & 104.6 & 107.6 & 75.8 & 78.4 & 84.6 \\
\hline 104.4 & 108.6 & 110.4 & 82.2 & 83.4 & 88.6 & 101.4 & 107.2 & 112.2 & 78.2 & 78.8 & 82.6 \\
\hline 101.8 & 106.8 & 109.4 & 78.6 & 80.4 & 90.2 & 106.6 & 109.2 & 111.8 & 80.8 & 82.2 & 88.4 \\
\hline
\end{tabular}

Table 3: 4th week data of weight and cholesterol levels (Mean and SD).

\begin{tabular}{|c|c|c|c|c|c|c|c|}
\hline A & B & $\mathbf{C}$ & D & $\mathbf{A}$ & $\mathbf{B}$ & $\mathbf{C}$ & D \\
\hline Weight (gm) & & & & \multicolumn{4}{|c|}{ Cholesterol (mg/dl) } \\
\hline \multicolumn{8}{|l|}{$4^{\text {th }}$ week } \\
\hline 100.2 & 110.4 & 106.2 & 111.2 & 74.4 & 101.2 & 84.2 & 87.8 \\
\hline 100.4 & 118.5 & 106.6 & 110.4 & 74.2 & 102.4 & 82.8 & 90.4 \\
\hline 101.4 & 120.4 & 110.4 & 108.2 & 78.2 & 106.4 & 85.6 & 85.2 \\
\hline 102.5 & 116.6 & 112 & 107.6 & 80.2 & 104.2 & 86.4 & 84.6 \\
\hline 101.1 & 121.2 & 110.4 & 112.2 & 75.3 & 106.4 & 88.6 & 82.6 \\
\hline 99 & 116.8 & 109.4 & 111.8 & 76.6 & 102.8 & 90.2 & 88.4 \\
\hline $100.77 \pm 1.19$ & $117.32 \pm 3.86$ & $109.17 \pm 2.3$ & $110.23 \pm 1.92$ & $76.48 \pm 2.35$ & $103.9 \pm 2.16$ & $86.3 \pm 2.74$ & $86.5 \pm 2.86$ \\
\hline
\end{tabular}

Table 2 shows bodyweight and blood cholesterol of animal of group ' $C$ ' $(n=6)$ and ' $D$ ' $(n=6)$ after administration of green tea $(10 \mathrm{mg} /$ day) and green coffee $(10 \mathrm{mg} /$ day) on start of experiment on $2^{\text {nd }}$ and $4^{\text {th }}$ week of experiment. Parameters of body weight and cholesterol in group $\mathrm{C}$ and D show the mild elevation of weight and cholesterol on $2^{\text {nd }}$ week, but significant elevation on $4^{\text {th }}$ week as compare with control group.

Data in Table 3 (mean and SD) presents the observation of weight and blood cholesterol on completion of experiment i.e., on $4^{\text {th }}$ week in all group of animals. There is approximately $17 \mathrm{gm}$ gain in weight and $27.42 \mathrm{mg} / \mathrm{dl}$ rise in cholesterol after giving high cholesterol diet $(\mathrm{p}<0.01)$. The rats in group ' $\mathrm{C}$ ' and ' $\mathrm{D}$ ' administered high cholesterol diet with green tea and green coffee respectively showed $8 \mathrm{gm}$ and $9 \mathrm{gm}$ of weight gain, that is approximately 8 to $9 \mathrm{gm}$ less than rats of group ' $\mathrm{B}$ ' $(\mathrm{p}<0.01)$.

Similarly rise in cholesterol level are $17 \mathrm{mg} / \mathrm{dl}$ less in groups treated with green tea and green coffee. The comparative changes in weight and cholesterol between group $\mathrm{C}$ and $\mathrm{D}$ are less significant, $(\mathrm{p}<0.5) \quad(\mathrm{p}<1)$ respectively.

Data mentioned in Table 4 presents the $p$-value within the groups which is compared by statistical analysis using two tailed t-test of unequal variance. Elevation of body weight and cholesterol between $\mathrm{A} / \mathrm{B}, \mathrm{B} / \mathrm{C}, \mathrm{B} / \mathrm{C}$ are significant and less significant between $\mathrm{C} / \mathrm{D}$.
Table 4: P-values within groups for alpha level $(0.01)$.

\begin{tabular}{|lll|}
\hline Groups & p values for weight & $\begin{array}{l}\text { p values for } \\
\text { cholesterol }\end{array}$ \\
\hline AB & $5.70 \mathrm{E}-05$ & $1.32 \mathrm{E}-09$ \\
\hline $\mathrm{BC}$ & 0.00217 & $6.06 \mathrm{E}-07$ \\
\hline $\mathrm{CD}$ & 0.40354 & 0.90416 \\
\hline $\mathrm{BD}$ & 0.000313 & $8.39 \mathrm{E}-07$ \\
\hline
\end{tabular}

\section{DISCUSSION}

The result of this experiment demonstrates significant role of green tea and green coffee on blood cholesterol and weight. Green tea is widely marketed for the use of reduction of weight or obesity and also for life style related health problems. ${ }^{9}$ According to many literature catechin with gallate ester in green tea is responsible for lowering cholesterol and weight. These ingredients of green tea interfere biliary micelle system in the lumen of intestine by forming insoluble co-precipitates of cholesterol and increasing fecal excretion of cholesterol. In addition, catechin have direct inhibitory effect on cholesterol synthesis. Several studies support that flavonoids and caffeine in green tea help in weight control of obese or overweight person, but more studies are required to make it significant. ${ }^{10,11}$ Chlorogenic acid and other natural antioxidants present in green coffee are thought to be active ingredients to promote weight loss. It has inhibitory effect on enzyme glucose -6-phosphatase reduces glucose 
absorption through intestine and inhibits fat accumulation. $^{12}$

In this experiment green tea and green coffee both have similar effect on cholesterol fed animals. There is satisfactory reduction of in cholesterol and weight as compare with experimentally induced hyper cholesterolemic animals. Along with benefit of this natural derived remedy side effects due to its content caffeine should be always taken into consideration.

\section{CONCLUSION}

This study has provided information about usefulness of green tea and green coffee in an important noncommunicable disease like dyslipidemia and obesity. These natural products may be helpful as preventive or as adjuvant in addition to others therapy in life style modification, but more research work is also required in this regard.

\section{ACKNOWLEDGEMENTS}

Authors would like to thank to Dr. Binod Kumar, Associate Professor, Department of Pathology, MGM Medical College, Jamshedpur for helping them for biochemical test, and to Mr. Samagra Kumar, Manager, Quality Assurance, LD\#2 and Slab Caster, Tata Steel Limited for statistical analysis.

\section{Funding: No funding sources}

Conflict of interest: None declared

Ethical approval: The study was approved by the Institutional Ethics Committee of MGM Medical College, Jamshedpur, Jharkhand, India

\section{REFERENCES}

1. Obesity and overweight -World Health Organisation. Available at: www.who.int/new-room/factsheet/detail/obesity-and-overwieght

2. Obesity, Kasper, Fauci, Hauser, Longo, Jameson, Loscalzo. Harrison's Manual of Medicine. $19^{\text {th }} \mathrm{Ed}$. New York, MacGraw-Hill Education (India) Pvt Ltd.; 2016:901-903.
3. Kris Gunnar, on Jan 17, 2018. 10 Proven Benefits of Green Tea-Health Line. Available at: https://www.healthline.com/nutrition/top-10.

4. Chacko SM, Thambi PT, Kuttan R, Nishigaki I. US National Library of Medicine, National Institute of health. Beneficial effect of green tea: a literature review. Available http:www.ncbi.nlm.nih.gov/pubmed/20370896

5. Amanolahi F, Rakhshande H. Effects of ethanolic extract of green tea on decreasing the level of lipid profile in rat. Avic J Phytomedic. 2013;3(1):98.

6. Namita P, Mukesh R, Vijay KJ. Camellia Sinensis (green tea): A review. Glo J Pharmacol. 2012;6(2):529.

7. Chlorogeneic Acid-scientific review on usageexamine.com-research analysis by Kamal Patel and verified by Examine.com. Research Team. Last updated June 14.2018, Available at: https://examine.com/supplements/chlorogenic-acid.

8. Green Coffee: Uses, Side Effects, Interaction Dosage. Available at:

https://www.webmd.com/vitamins/ai/ingredientmono $-1264 /$ green-coffee

9. Clement Y. Can green tea do that? A literature review of the clinical evidence. Preventive medicine. 2009 Aug 1;49(2-3):83-7.

10. Xin-xin Z, Yan-Lu X. Shao-Hua L. Green tea intake lowers fasting serum total and LDL cholesterol in adult. Ameta analysis of 14 randomised controlled trials. Ame J Clin Nutrit. 2011;94(2):601-10.

11. Koo SI, Noh SK. Green tea as inhibitor of the intestinal absorption oflipids: potential mechanism for its lipidlowering effect. J Nutr Biochem. 2007;18:179-83.

12. Buchanan R, Beckett RD. Green coffee for Pharmacological weight loss. J Evi Bas Complemen Alter Medici. 2013;18(4):309-13.

Cite this article as: Kumar R, Purty MK.

Comparative evaluation of effect of green tea and green coffee on blood cholesterol level and body weight in albino rats. Int $\mathrm{J}$ Basic Clin Pharmacol 2018;7:2053-6. 